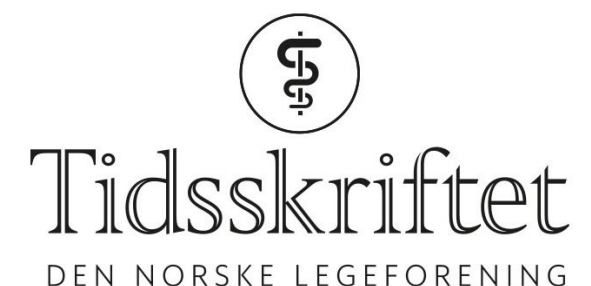

DEN NORSKE LEGEFORENING

\title{
Øyvind Bekkhus
}

MINNEORD

JENS A. MØRCH

KNUT BOE KIELLAND

Øyvind Bekkhus døde 31. august, 87 år gammel. Med det er en markant allmennlege og kommunelege gått bort. Han kom fra en lærerfamilie i Telemark og ble cand.med. i 1959. Deretter arbeidet han på hudavdeling, som dykkerlege, allmennlege og bergverkslege, før han i 1966 kom til Moss. Der bidro han til å danne landets første gruppepraksis, samtidig som han var aktiv i arbeidet med videreutdanning. Han ble allmennpraktiker Dnlf(senere spesialist i allmennmedisin) i 1973 .

I 1977 kom han til Hov i Søndre Land - et sted som kanskje hadde noen av de kvalitetene han kjente fra Telemark. Og der ble han. Han deltok i etableringen av Hov legesenter, først alene, så med flere leger i et godt, hyggelig og veldrevet kontorfellesskap. Turnuskandidater og medisinerstudenter fra Universitetet i Oslo hørte med. Da man i 1992 hadde vansker med å rekruttere leger til kommunens andre legekontor, valgte han å bytte praksissted til Odnes, 17-18 km nord for Hov. Mange pasienter kom etter - til tross for lengre reisevei.

Han var kommunens samfunnsmedisiner i en årrekke og fikk satt folkehelse på den kommunale dagsorden lenge før det ble "på moten». Bekymringen for inaktiv ungdom førte til at han offentlig anbefalte at skolebarn burde gå fra Hov sentrum til skolen - en strekning på snaut $2 \mathrm{~km}$ - framfor å ta bussen helt fram. Det var opptakten til FYSAK-tiltakene, som siden har satt Søndre Land på kartet som foregangskommune til å inkludere fysisk aktivitet i skolen. Han praktiserte selv i stor grad det han anbefalte - på sykkel, i skog og mark og på Hov treningssenter.

Funksjonen som offentlig lege overlot han til andre i 1998 for å bruke resten av sin yrkesaktive tid til pasienter direkte som fastlege.

Han trivdes med pasientene, og pasientene trivdes med ham. Han holdt seg godt faglig oppdatert, og det var motvillig han måtte gi seg da han fylte 75 år, som den gang var aldersgrensen for autorisasjon. En erstatning var nok at han som pensjonist i perioder ledet spinningen på treningssenteret. Samtidig argumenterte han i Tidsskriftet for at leger burde kunne fungere lenger i praksis forutsatt passende kontroll. Aldersgrensen for autorisasjon ble for øvrig hevet til 8o år i 2015.

Vi minnes en helstøpt kollega, i takknemlighet for alt han har betydd for familien, kommunen, for kollegiet, for oss personlig - og framfor alt: for pasientene.

Vår tanker går til Inger og resten av den store familien. 
Publisert: 26. oktober 2020. Tidsskr Nor Legeforen. DOI:10.4045/tidsskr.20.0756

(C) Tidsskrift for Den norske legeforening 2020. Lastet ned fra tidsskriftet.no 